\title{
Electrocardiographic study on geriatric dogs undergoing general anesthesia with isoflurane
}

\author{
Estudo eletrocardiográfico em cães geriátricos submetidos à anestesia geral com isofluorano
}

\author{
Andreza Conti-Patara ${ }^{\mathrm{I} *}$ Denise Tabacchi Fantoni ${ }^{\mathrm{I}}$ Silvia Renata Gaido Cortopassi ${ }^{\mathrm{I}}$
}

\section{ABSTRACT}

The purpose of this study was to clarify the degree of influence of anesthetic agents commonly used during anesthesia on the heart conduction systems of geriatric dogs, with or without the presence of electrocardiographic changes in the pre-anesthetic electrocardiogram and also to determine the possible causes of ST-segment and T-wave changes during anesthesia, by monitoring ventilation and oxygenation. 36 geriatric dogs were evaluated. In addition to electrocardiographic evaluation, the pre-anesthetic study included serum levels of urea, creatinine, total protein, albumin and electrolytes. The pre-anesthetic medication consisted of acepromazine $\left(0.05 \mathrm{mg} \mathrm{kg}^{-1}\right)$ in association with meperidine (3.0 mg kg-1) by IM injection. Anesthesia was induced with propofol (3.0 to $5.0 \mathrm{mg} \mathrm{kg}^{-1}$ ) by IV injection and maintained with isoflurane in $100 \%$ oxygen. During the anesthesia, the animals were monitored by continued computerized electrocardiogram. Systemic blood pressure, heart rate, respiratory rate, end-tidal carbon dioxide, partial pressure of carbon dioxide in arterial blood, arterial oxygen saturation, partial pressure of arterial oxygen and oxygen saturation of hemoglobin were closely monitored. During maintenance anesthesia, normal sinus rhythm was more common (78\%). ST-segment and T-wave changes during the anesthetic procedure were quite common and were related to hypoventilation. The use of isoflurane did not result in arrhythmia, being therefore a good choice for this type of animal; Electrocardiographic findings of ST-segment and Twave changes during the maintenance anesthesia were evident in animals with hypercapnia, a disorder that should be promptly corrected with assisted or controlled ventilation to prevent complicated arrhythmias.

Key words: anesthesia, dog, electrocardiography, geriatrics.

\section{RESUMO}

Os objetivos deste estudo foram esclarecer a influência dos agentes anestésicos comumente utilizados durante a anestesia no sistema de condução cardíaco em cães idosos, com ou sem alterações eletrocardiográficas prévias, e determinar as possíveis causas de alterações no segmento ST e onda $T$ durante a anestesia, por meio da monitoração da ventilação e da oxigenação. Para tanto, foram avaliados 36 cães idosos. Os exames pré-anestésicos incluíram o eletrocardiograma e os níveis séricos de uréia, creatinina, proteína total, albumina e eletrólitos. A medicação préanestésica foi realizada com acepromazina $\left(0,05 \mathrm{mg} \mathrm{kg}^{-1}\right)$ associada à meperidina $\left(3,0 \mathrm{mg} \mathrm{kg}^{-1}\right)$ por via intramuscular. A indução da anestesia foi realizada com propofol $e$ a manutenção foi feita com isofluorano com oxigênio a $100 \%$. Durante a anestesia, os animais foram monitorados continuamente com um eletrocardiógrafo computadorizado. A pressão arterial sistêmica, a freqüência cardíaca, a freqüência respiratória, o dióxido de carbono expirado, a pressão parcial arterial de dióxido de carbono, a saturação de oxigênio arterial, a pressão parcial de oxigênio arterial e a saturação de oxigênio na hemoglobina também foram monitorados durante a anestesia. Durante a manutenção da anestesia, 78\% dos animais apresentaram ritmo sinusal normal. As alterações no segmento ST e onda $T$ foram freqüentes e relacionadas à hipoventilação. $O$ isofluorano não promoveu o aparecimento de arritmias, sendo assim um fármaco indicado em animais idosos. As alterações em segmento ST e onda T foram evidentes em animais com hipercapnia. A correção da hipercapnia deve ser implementada por meio de ventilação controlada e/ou assistida a fim de prevenir arritmias mais complicadas.

Palavras-chave: anestesia, cães, eletrocardiografia, geriátricos.

\footnotetext{
IDepartamento de Cirurgia, Faculdade de Medicina Veterinária e Zootecnia (FMVZ), Universidade de São Paulo (USP). Av. Prof. Dr. Orlando Marques de Paiva, 87, Cidade Universitária, 05508-900, São Paulo, SP, Brasil. E-mail: acontipatara@yahoo.com.br. *Autor para correspondência.
} 


\section{INTRODUCTION}

Electrocardiographic assessment during the anesthesia is very important in order to monitor heart rate and rhythm, in addition to the close assessment of electrolytic balance and oxygenation of the patient (COHEN \& TILLEY, 1979). Aging is responsible for the degenerative changes seen in the heart conduction systems. These changes make the geriatric patient more prone to developing arrhythmia during the anesthetic procedure (PADDLEFORD, 1999). Therefore, electrocardiographic assessment during the anesthesia is of fundamental importance to prevent more complicated arrhythmias in geriatric animals which undergo a stressful situation such as a surgical and anesthetic procedure (PADDLEFORD, 1999). The purpose of this study was to clarify the degree of influence of anesthetic agents commonly used during anesthesia on the heart conduction systems of geriatric dogs, with or without the presence of electrocardiographic changes in the pre-anesthetic electrocardiogram and also to determine the possible causes of ST-segment and T-wave changes during anesthesia, by monitoring ventilation and oxygenation.

\section{MATERIAL AND METHODS}

Thirty-six geriatric, small-size dogs, 15 females and 21 males of different breeds (Table 1), obtained from the Surgery Service of the Veterinary Hospital of the Veterinary Medicine and Zootechny School of São Paulo University were included in the study. Small size was defined as animals of up to $10 \mathrm{~kg}$ and geriatric was defined as those which had reached at least $75 \%$ of the expected life span for that particular breed and size: 9 to 13 years (GOLDSTON, 1989). The animals selected were those included in risk category 2 and they underwent surgical procedure lasting at least 60 minutes, regardless of the type of surgery performed; parameters were statistically evaluated up to 75 minutes of anesthesia.

The animals were evaluated by the Cardiology Service, where the pre-anesthetic electrocardiogram was measured. Pre-anesthetic exams included after cardiac assessment, complete blood count, total protein and albumin, serum levels of creatinine and urea. Additionally, serum levels of sodium, potassium and ionized calcium were measured by means of a multi-parametric analyzer ${ }^{a}$ using an appropriate kit, and magnesium was measured by spectrophotometry ${ }^{\mathrm{b}}$. In the pre-anesthetic evaluation, the heart rate and respiratory rate, mean, systolic and non-invasive diastolic blood pressure, temperature, capillary filling time, color of the mucosae, and degree of hydration were measured. Dogs with altered values for renal function, hemogram, total plasma proteins, albumin, and electrolytes and the dogs that received any medication for the heart were not included in the study. Following the assessment, the animals were pretreated with acepromazine ${ }^{\mathrm{c}} 0.05 \mathrm{mg} \mathrm{kg}^{-1}$ and meperidine ${ }^{\mathrm{d}}$ $3.0 \mathrm{mg} \mathrm{kg}^{-1}$ by IM injection. After 15 minutes, a postmedication, pre-anesthetic assessment was conducted and included heart rate, respiratory rate, blood pressure, temperature, capillary filling time, color of the mucosae, and degree of hydration. Anesthesia was induced with intravenous propofol ${ }^{\mathrm{e}} 3.0$ to $5.0 \mathrm{mg} \mathrm{kg}^{-1}$ by IV injection. Following intubation, the animal was kept on inhaled anesthesia $^{\mathrm{f}}$ with isoflurane ${ }^{\mathrm{g}}$ in $100 \%$ oxygen, with the aid of a circular circuit. When necessary, during the anesthesia, intravenous fentanyl ${ }^{\mathrm{h}} 5 \mu \mathrm{g} \mathrm{kg}^{-1}$ by intravenous injection was administered in order to enhance trans-operative analgesia, and reduce the concentration of the inhaled anesthetic agent. During the trans-operative period, the animal was continuously monitored using a computerized electrocardiograph ${ }^{\mathrm{i}}$ simultaneously showing the 10 leads used in the assessment of dogs (DI, DII, DIII, aVR, aVL, aVF, CV5RL, CV6LL, CV6LU, V10). Cardiac rhythm, heart rate, PR interval, range and morphology of the QRS complex, the ST-segment, and morphology, range and polarity of the T-wave were measured. Mean, systolic, and diastolic blood pressure were also assessed using a non-invasive blood pressure monitor ${ }^{\mathrm{j}}$. Respiratory rate was assessed by observation of the thoracic movements, and ventilation by observation of the expired carbon dioxide levels, constantly being displayed by a gas analyzerk connected to the "T" outlet. Oxygenation was assessed by pulse oximetryl, using a sensor attached to the tongue of the animal or to glabrous non-pigmented skin. Arterial blood samples were obtained every 30 minutes, starting immediately after the administration of the pre-anesthetic medication, and gasometrical assessment was performed using a $\mathrm{pH}$ and blood gas analyzer ${ }^{\mathrm{m}}$. Only the values obtained every 15 -minute time points were considered for evaluation; time zero being the moment when anesthesia was induced. The results obtained were statistically confronted by parametric testing, using variance analysis for repeated measures followed by Tukey's test to compare the different evaluation time points throughout the anesthesia. The level of significance established was $5 \%(\mathrm{P}<0.05)$. ST-segment, $\mathrm{T}$-wave and cardiac rhythm were assessed by the frequency of abnormalities of occurrence in the group. 
Table 1 - Description of the dogs included in the study: age, weight, breed, sex and surgery.

\begin{tabular}{|c|c|c|c|c|c|}
\hline Dogs & Breed & Age (years) & Weight (kg) & Sex & Surgery \\
\hline 1 & pinscher & 9 & 7 & male & arthroplasty \\
\hline 2 & mongrel & 9 & 11 & female & Excision of skin cancer \\
\hline 3 & mongrel & 10 & 7 & male & Excision of skin cancer \\
\hline 4 & teckel & 10 & 7 & female & Ablation of conduct hearing \\
\hline 5 & poodle & 10 & 10 & female & Excision of skin cancer \\
\hline 6 & mongrel & 10 & 10 & female & hemimandibulectomy \\
\hline 7 & pinscher & 6 & 3,6 & female & Excision of skin cancer \\
\hline 8 & Brazilian terrier & 11 & 7,4 & female & Excision of skin cancer \\
\hline 9 & poodle & 9 & 5 & female & Excision of skin cancer \\
\hline 10 & mongrel & 13 & 7,4 & male & Perineum herniorrhaphy \\
\hline 11 & Poodle & 14 & 4,3 & male & Perineum herniorrhaphy \\
\hline 12 & poodle & 9 & 10 & male & Limb Amputation \\
\hline 13 & Brazilian terrier & 13 & 10,3 & male & Hemimandibulectomy \\
\hline 14 & yorkshire & 15 & 2,3 & male & Perineum herniorrhaphy \\
\hline 15 & poodle & 9 & 7 & male & Osteosynthesis \\
\hline 16 & mongrel & 12 & 6 & female & Excision of skin cancer \\
\hline 17 & pinscher & 10 & 4,3 & male & Ablation of conduct hearing \\
\hline 18 & schinauzer & 9 & 6 & female & Cystotomy \\
\hline 19 & poodle & 9 & 7 & male & Cystotomy e orchiectomy \\
\hline 20 & mongrel & 15 & 10 & male & orchiectomy \\
\hline 21 & poodle & 12 & 3,5 & male & orchiectomy \\
\hline 22 & pinscher & 10 & 4,2 & male & Ablation of conduct hearing \\
\hline 23 & poodle & 9 & 10,0 & male & Excision of perineum cancer \\
\hline 24 & pinscher & 10 & 3,2 & female & Facectomy \\
\hline 25 & poodle & 12 & 9,4 & female & Excision of skin cancer \\
\hline 26 & poodle & 12 & 5,1 & male & Excision of skin cancer \\
\hline 27 & Lhasa-apso & 10 & 4,3 & male & Facectomy \\
\hline 28 & mongrel & 13 & 6,0 & female & Rhinoscopy \\
\hline 29 & teckel & 14 & 7,0 & female & Excision of skin cancer \\
\hline 30 & poodle & 10 & 10,0 & male & Excision of skin cancer \\
\hline 31 & mongrel & 11 & 8,5 & female & Mastectomy \\
\hline 32 & Lhasa-apso & 11 & 9,2 & male & Perineum herniorrhaphy \\
\hline 33 & poodle & 12 & 8,5 & male & Limb amputation \\
\hline 34 & Lhasa-apso & 11 & 7,0 & male & Hemimandibulectomy \\
\hline 35 & pinscher & 9 & 4,0 & female & Excision of perineum cancerão de \\
\hline 36 & mongrel & 11 & 9,1 & male & Osteosynthesisosteossíntese \\
\hline
\end{tabular}

\section{RESULTS AND DISCUSSION}

In the study group, the pre-anesthetic electrocardiogram revealed a first-degree atrioventricular block in $3 \%$ of the animals, Type I Mobitz second-degree atrioventricular block in 3\% of the animals, and sinus pauses in $11 \%$ of the animals showing that overall, $17 \%$ of the animals could have degenerative alterations in the conduction system as a result of aging. $41 \%$ of the animals had sinus arrhythmia, 39\% of the dogs had normal sinus rhythm and $3 \%$ had sinus tachycardia. When compared to young animals, the elderly have multiple pathophysiological conditions (PADDLEFORD, 1999).
Aging is associated with the structural and functional changes in the cardiac pacemaker and in its conduction system. An increase of collagen between the tissue cells of the atrioventricular node and common His bundle may also occur, thus reducing the velocity of impulse conduction in these segments (SCHMIDLIN et al., 1992).

During the trans-anesthetic period, the prolonged PR interval observed is important from the biological point of view since $8 \%$ of the animals with normal PR interval and sinus rhythm evolved to firstdegree atrioventricular block (AVB) (Figure 1), however, without hemodynamic impairment. During the trans-operative period, atrioventricular and sinoatrial 


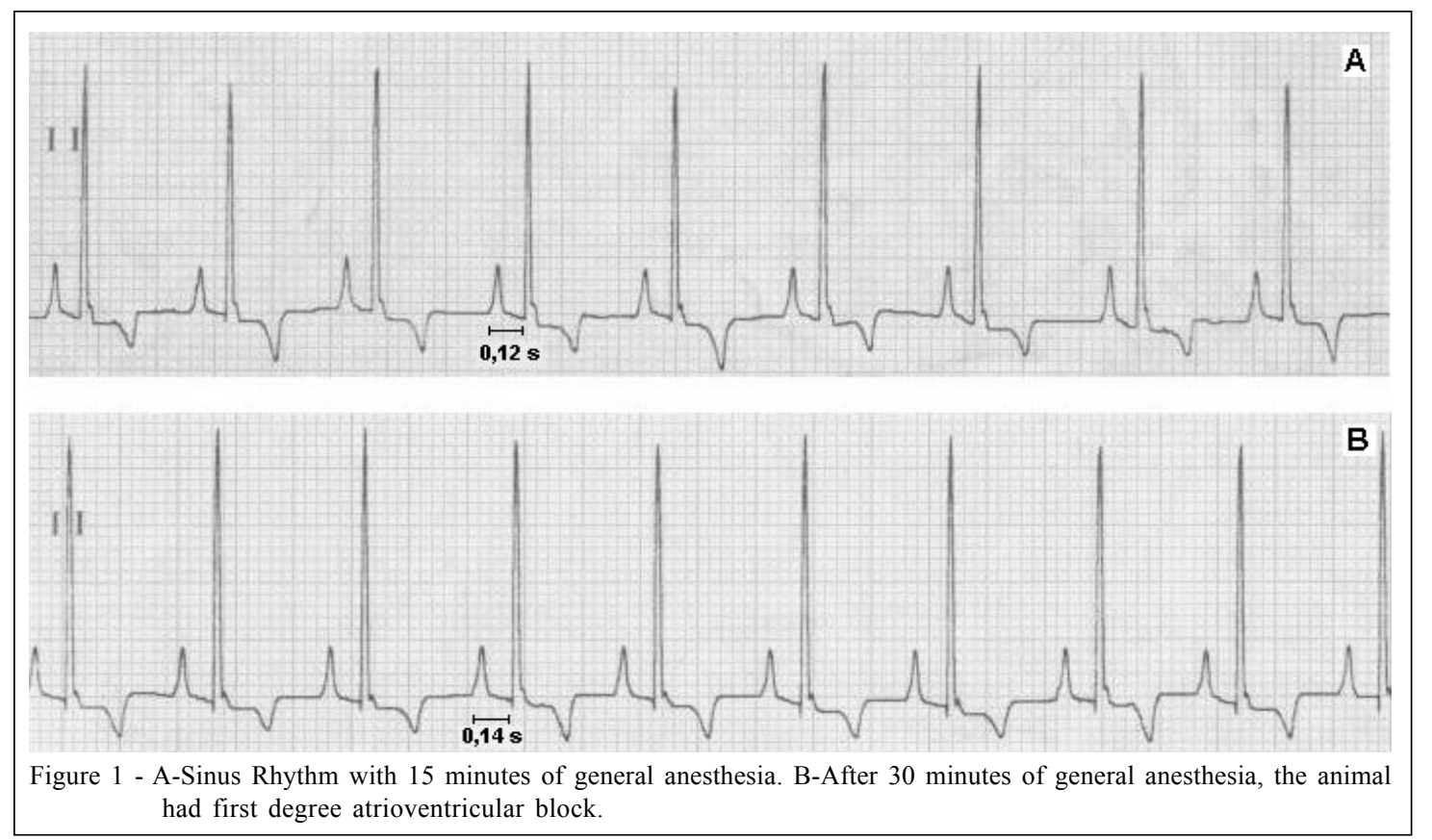

blocks may be caused by drugs such as phenothiazines that promote increased vagal tonus (MUIR, 1993). The likelihood of the phenothiazinic agent causing the atrioventricular blocks cannot be discarded, considering that two animals had second-degree AVB prior to the induction of the anesthesia.

As regards changes in cardiac rhythm, we must mention the occurrence of sinus tachycardia $-\mathrm{a}$ frequent rhythm during anesthesia, not necessarily related to the superficial plane of anesthesia but may be compensatory to severe hypotension, or result from the use of vagolytic drugs or catecholamine (NUNES, 2002). During the trans-anesthetic period, at $15 \mathrm{~min}$ of the inalatory anesthesia, $5 \%$ of the study animals had sinus tachycardia associated with the superficial plane of anesthesia. Sinus tachycardia promotes shortening of diastolic time, a period during which coronary flow predominates, thus reducing myocardial perfusion (CHAGAS, 2000). Simultaneously, the tachycardia increases the workload of the cardiac pump and the consumption of oxygen by the cardiac muscle. As a result of the increased consumption of oxygen and inadequate supply, the cardiac muscle becomes prone to hypoxia. This may be aggravated by degenerative cardiac diseases that are commonly found in geriatric animals (DODMAN et al., 1984), which already cause higher myocardial oxygen consumption (PADDLEFORD, 1999). During the trans-anesthetic period, heart rate remained stable, although slightly higher than after the administration of the preanesthetic medication (Post MPA) probably due to the effect of isoflurane. In concentrations of up to $2 \mathrm{MAC}$, the isoflurane helps to maintain cardiac output, increasing heart rate baseline values up to $20 \%$ (AMARAL, 1996). Therefore, isoflurane is the inhalation anesthetic of choice for animals with cardiac diseases (STEFFEY, 1996).

As regards pre-anesthetic medication, the activity of acepromazine, the phenothiazinic used in this study, shows specificity for the afferent sensorial routes to reticular formation, limbic structures and diffuse thalamic-cortical projections. Thus it reduces vasomotor tonus, justifying the tranquility, sedation, vasodilatation and ataxia produced (SPINOSA \& GÓRNIAK, 1999). In this study, blood pressure measures revealed no significant difference between pre and post pre-anesthetic medication (Table 1), confirming that the intramuscular dose of acepromazine used $\left(0.05 \mathrm{mg} \mathrm{kg}^{-1}\right)$ results in adequate level of tranquilization without promoting hypotension.

During inhaled anesthesia, seven animals (19\%) had hypotension and four of these (11\%), had their blood pressure normalized solely by reducing isoflurane concentration in $10 \%$. Introduction of vasoactive medication was required in only two animals. Isoflurane induces significant hypotension as a result of reduced peripheral vascular resistance. Therefore, it should be used with caution in animals in shock or suffering from hypotension (STOELTING, 1999).

The elderly individuals have reduced baroreflex activity. This reduction results in a reduced response to blood loss during the trans-operative 
period. As a result, the ability to adapt to hypotension and to the self-regulation of the cardiovascular system is reduced in geriatric individuals who become more sensitive to cardiovascular depression and hypotension caused by the majority of anesthetic agents (OWENS, 1985). Although the geriatrics are more sensitive to cardiovascular depression and hypotension caused by the majority of anesthetic agents, in the group studied, we observed they easily recovered the systemic blood pressure after the reduction of the concentration of the inhaled anesthetic agent.

Geriatric individuals may develop respiratory system impairment. With age, there is a qualitative deterioration of pulmonary elastin and reduced complacency of the thoracic walls that promotes deterioration of ventilation and of efficient gas interchange (TOLDO et al., 2001). In addition to the physiological changes in the respiratory system of geriatric individuals, isoflurane also promotes intense respiratory depression, with decreased volume/minute and increased levels of carbon dioxide in the arterial blood $\left(\mathrm{PaCO}_{2}\right.$ ) (AMARAL, 1996). In the present study, a significant reduction in respiratory rate values was observed at 15, 30, 45 and $60 \mathrm{~min}$ compared to preanesthetic values. Likewise, the values obtained at $30 \mathrm{~min}$ were lower compared to those obtained at the post-MPA and extubation time points (Table 2). These dogs underwent controlled and/or assisted ventilation, since after 15 minutes of inhalatory anesthesia at the time point of the first arterial blood samples for gasometry, $\mathrm{PaCO}_{2}$ levels were higher or equal to $45 \mathrm{mmHg}$, with a tendency to respiratory acidosis as a result of hypoventilation.

Clearly, geriatric animals undergoing anesthesia and spontaneous ventilation are more prone to developing hypoxia when compared to younger animals (ROBINSON, 1993). Hypoxia and hypercapnia promote cardiac arrhythmias triggered indirectly by catecholamines, and directly by cardiac cell depression and by stimulation of the vasomotor centers of the brain (HUBBEL et al., 1984). From the electrocardiographic viewpoint, changes in the STsegment (elevation or depression) and in the morphology of the T-wave may be associated with myocardial hypoxia, hypercapnia, electrolytic abnormalities, and cardiac hypertrophy (ETTINGER, 2000). The serum levels of calcium, sodium, potassium and magnesium were within normal limits; therefore, the electrocardiographic changes observed were not associated with the electrolytic disorders. The STsegment should not be assessed exclusively in lead DII, since mild ST- segment changes are not necessarily visible in this lead, requiring the assessment of this segment in the precordial leads (NUNES, 2002), as observed in four animals (11\%).

The analysis of ST-segment in lead DII and in the precordial leads showed ST changes during the trans-anesthetic period associated with hypercapnia (Figure 2). Two animals (6\%) showed ST segment

Table 2 - Mean and Standard deviation of heart rate (beats per minute), systolic, mean and diastolic blood pressure (mmHg), respiratory rate (movements per minute), end-tidal carbon dioxide [concentration] $\left(\mathrm{ETCO}_{2}\right)(\mathrm{mmHg})$, peripheral saturation of oxihemoglobin $\left(\mathrm{P}_{\mathrm{S}} \mathrm{O}_{2}\right)$ in per cent $(\%)$, arterial $\mathrm{pH}$, partial pressure of oxygen in arterial blood $\left(\mathrm{PaO}_{2}\right)$ in millimeters of mercury $(\mathrm{mmHg})$, partial pressure of carbon dioxide in arterial blood $\left(\mathrm{PaCO}_{2}\right)(\mathrm{mmHg})$, plasma bicarbonate $\left(\mathrm{HCO}_{3}{ }^{-}\right)\left(\mathrm{mmol}^{-1}\right)$, oxygen saturation in arterial blood $\left(\mathrm{SaO}_{2}\right)$, isofuorane inspiratory concentration (Fi Iso), and isofluorane expiratory concentration (ET Iso) at different evaluation time points.

\begin{tabular}{|c|c|c|c|c|c|c|c|c|}
\hline Parameter & Pre-MPA & Post- MPA & $15 \mathrm{~min}$ & $30 \mathrm{~min}$ & $45 \mathrm{~min}$ & $60 \mathrm{~min}$ & $75 \mathrm{~min}$ & extubation \\
\hline HR & $128.69 \pm 30.2$ & $98.19 \pm 26.2$ & $105.75 \pm 31.5$ & $104.92 \pm 25.9$ & $105.67 \pm 26.21$ & $101.53 \pm 31.1$ & $97.05 \pm 22.7$ & $123.62 \pm 37.6$ \\
\hline SBP & $119.8 \pm 25.2$ & $114.4 \pm 17.4$ & $98.6 \pm 22.1$ & $102.8 \pm 25.1$ & $99.1 \pm 18.9$ & $101.3 \pm 21.1$ & $102.8 \pm 22.0$ & $110.5 \pm 21.6$ \\
\hline MBP & $93.3 \pm 23.9$ & $87.4 \pm 18.8$ & $74.9 \pm 20.7$ & $80.9 \pm 23.3$ & $76.8 \pm 17.0$ & $80.1 \pm 16.6$ & $79.4 \pm 18.2$ & $86.6 \pm 14.0$ \\
\hline DBP & $73.7 \pm 18.0$ & $70.3 \pm 15.1$ & $57.5 \pm 18.3$ & $62.9 \pm 18.9$ & $59.3 \pm 15.0$ & $60.7 \pm 16.0$ & $61.8 \pm 15.4$ & $65.0 \pm 19.6$ \\
\hline RR & $28.6 \pm 8.2$ & $24.5 \pm 7.5$ & $18.5 \pm 10.0 *$ & $17.6 \pm 7.2 *$ & $20.6 \pm 8.4^{*}$ & $20.7 \pm 9.6^{*}$ & $24.3 \pm 12.1$ & $27.91 \pm 14.38$ \\
\hline ETCO2 & & & $34.5 \pm 9.4$ & $34.0 \pm 8.9$ & $31.6 \pm 7.4$ & $30.8 \pm 6.8$ & $29.3 \pm 5.3$ & $33.7 \pm 10.3$ \\
\hline $\mathrm{SpO} 2$ & & & $99.4 \pm 0.9$ & $99.4 \pm 0.9$ & $99.5 \pm 0.7$ & $99.4 \pm 0.8$ & $99.7 \pm 0.6$ & $99.8 \pm 0.4$ \\
\hline PH & & & $7.3 \pm 0.1$ & & $7.3 \pm 0.07$ & & & \\
\hline $\mathrm{PaO}_{2}$ & & & $353.1 \pm 128.1$ & & $328.4 \pm 132.2$ & & & \\
\hline $\mathrm{PaCO}_{2}$ & & & $42.2 \pm 11.4$ & & $38.9 \pm 9.7$ & & & \\
\hline $\mathrm{HCO}_{3}{ }^{-}$ & & & $20.5 \pm 3.0$ & & $19.4 \pm 3.1$ & & & \\
\hline $\mathrm{SaO}_{2}$ & & & $99.8 \pm 0.4$ & & $99.8 \pm 0.4$ & & & \\
\hline Fi Iso & & & $1,76 \pm 0,46$ & $1,60 \pm 0,53$ & $1,63 \pm 0,37$ & $1,35 \pm 0,39$ & $1,35 \pm 0,54$ & $0,33 \pm 0,16$ \\
\hline ET Iso & & & $1,44 \pm 0,4$ & $1,39 \pm 0,48$ & $1,41 \pm 0,37$ & $1,15 \pm 0,3$ & $1,07 \pm 0,44$ & $0,21 \pm 0,09$ \\
\hline
\end{tabular}

* A significant reduction in respiratory rate values was observed at 15, 30, 45 and 60min compared to pre-anesthetic values (respectively $\mathrm{P}<0.001, \mathrm{P}<0.001, \mathrm{P}<0.01$ and $\mathrm{P}<0.01)$ 


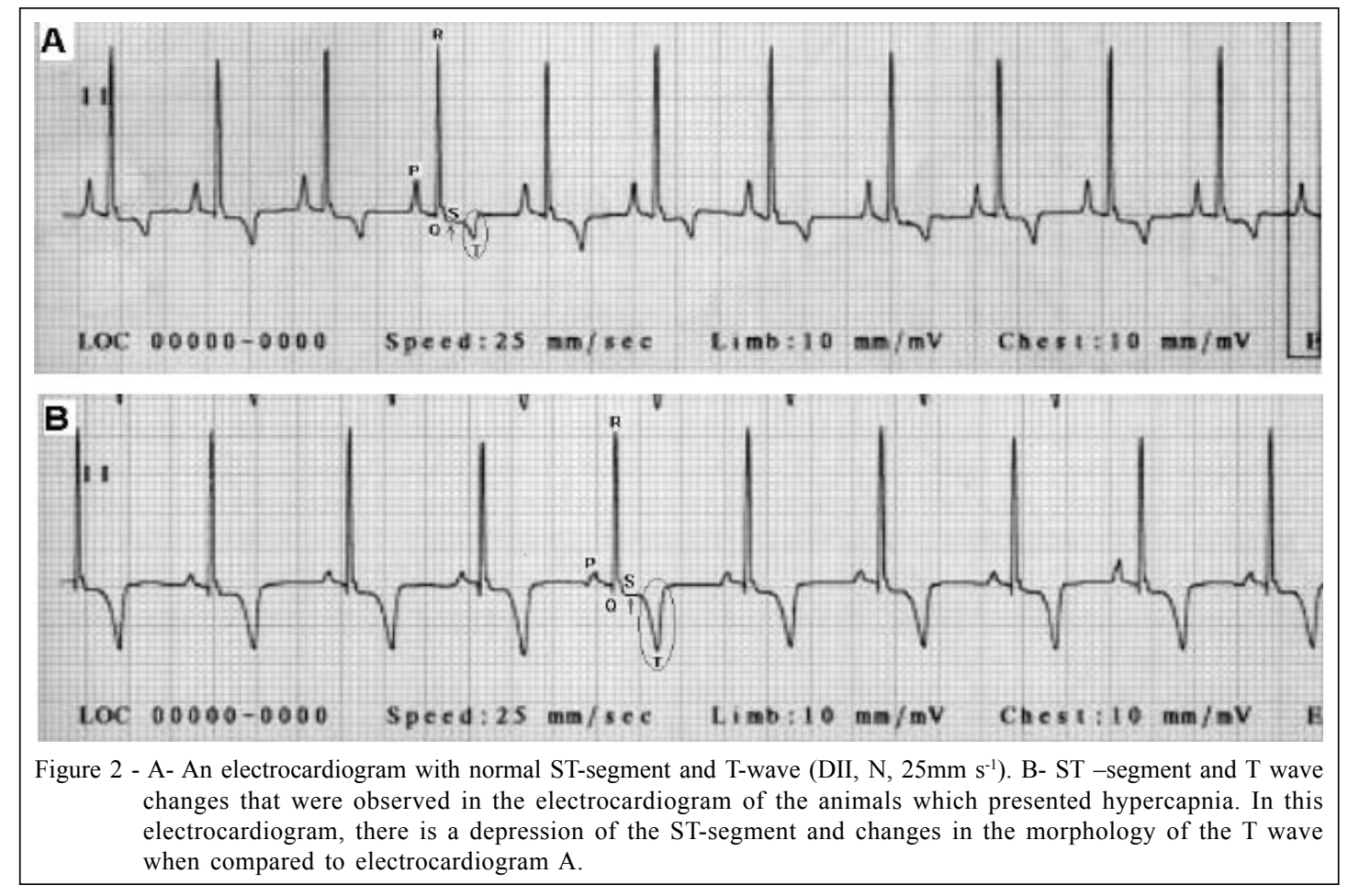

changes concomitant with hypercapnia and hypotension, and four animals (11\%) showed ST segment changes concomitant only with hypotension at $45 \mathrm{~min}$ of anesthesia. An evaluation of T-wave morphology, range and polarity also showed alterations: nine animals $(25 \%)$ showed T-wave morphological changes at $15 \mathrm{~min}$ and $30 \mathrm{~min}$ of anesthesia that were related with hypercapnia; two animals (5\%) showed TWave morphological changes concomitant with hypercapnia and hypotension, and four animals (11\%) showed T-wave morphological changes concomitant only with hypotension at $15 \mathrm{~min}$ and $30 \mathrm{~min}$ of anesthesia. In the study group, $16 \%$ of the animals showed T-wave polarity inversion related to hypoventilation and hypercapnia; T-wave polarity inversion during the anesthetic procedure suggests myocardial hypoxia and the ventilation and oxygenation status of the patient must be evaluated (BOLTON, 1975).

Myocardial hypoxia must be identified and treated immediately, either by correction of the heart rate, if the heart rate is high, or by correction of ventilation or even by the use of coronary vasodilators. Failure to identify this abnormality occasionally results in worsening of the symptoms that may evolve to sustained ventricular arrhythmia, fibrillation and asystolia (NUNES, 2002). The decision to treat electrocardiographic alterations during the transanesthetic period will depend on the global cardiac status of the patient. If the arrhythmia is causing major hemodynamic changes, the intervention of the anesthesiologist is paramount to prevent cardiovascular collapse (ZAIDAN, 1993).

\section{CONCLUSIONS}

From the results obtained it was possible to conclude that from the electrocardiographic viewpoint, the first degree atrioventricular block observed in geriatric animals is likely to occur as a result of the administration of acepromazine without, however, causing circulatory alterations that could jeopardize the physical integrity of the animals; the use of isoflurane in concentrations around the 1 CAM and a half did not promote arrhythmia, and enhanced hemodynamic stability, being a good choice for this type of animals; geriatric animals have a great tendency to develop hypoventilation and hypercapnia, therefore, close monitoring is required in addition to ventilation if necessary; Identification of this disorder through continued electrocardiographic monitoring and its correction, through the use of assisted or controlled ventilation is highly important in order to prevent more complicated arrhythmias.

\section{ACKNOWLEDGEMENTS}

The authors thank the FAPESP (Foundation of Support to Research of the State of São Paulo) for financial support.

Ciência Rural, v.39, n.2, mar-abr, 2009. 


\section{SOURCES AND MANUFACTURES}

aMulti-parametric analyzer: i-STAT Corporation, New Jersey, USA.

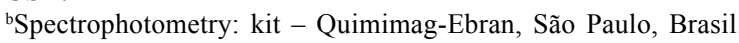

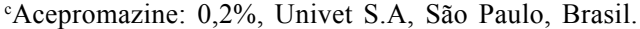

${ }^{\mathrm{d}}$ Meperidine (Dolosal): $50 \mathrm{mg} / \mathrm{ml}$, Cristália Produtos Químicos Farmacêuticos Ltda, São Paulo, Brasil.

ePropofol: Cristália Produtos Químicos Farmacêuticos Ltda, São Paulo, Brasil.

${ }^{f}$ Aparelho de Anestesia - Samurai III, vaporkettle mod 1415 microprocessado, Takaoka

gIsoflurane: Abbott Produtos Hospitalares., Saõa Paulo, Brasil. hFentanyl: Cristália Produtos Químicos Farmacêuticos Ltda, Itapira, São Paulo, Brasil.

${ }^{i}$ Computerized electrocardiograph: Agilent Technologies, Andover, USA..

${ }^{\mathrm{j} N o n-i n v a s i v e ~ b l o o d ~ p r e s s u r e ~ m o n i t o r: ~ C r i t i c a r e ~ S y s t e m s, ~}$ Takaoka, São Paulo, Brasil.

${ }^{k}$ Gas analyzer: Anesthetic Gas Analyzer and Oxi-capnograph, Datascope., São Paulo, Brasil.

${ }^{1}$ Oximetry: Anesthetic Gas Analyzer and Oxi-capnograph, Datascope, São Paulo, Brasil.

${ }^{\mathrm{m}} \mathrm{pH}$ and blood gas analyzer: ABL-5, Radiometer, Copenhagen, Denmark.

\section{BIOETHICS AND BIOSSECURITY COMMITTEE APPROVAL}

This study was approved by Bioethic Committee of Veterinary Medicine and Zootechny School of São Paulo University (FMVZ-USP).

\section{REFERENCES}

AMARAL, J.L.G. Efeitos cardiovasculares dos anestésicos inalatórios. In: BRAZ, J.R.C. et al. O sistema cardiovascular e a anestesia. São Paulo: Unesp, 1996. p.51-54.

BOLTON, G.R. The eletrocardiogram. In: BONAGURA, J.D., MUIR, W.W. Handbook of canine eletrocardiography. Philadelphia: Saunders, 1975. p.39-88.

CHAGAS, A.C.P. Fisiopatologia da circulação coronariana. In: Fisiopatologia cardiovascular. São Paulo: Atheneu, 2000. p.77-88

COHEN, R.B.; TILLEY, L.P. Cardiac arrhythmias in the anesthetized patient. Vet Clin North Am Small Anim Pract, v.9, p.155-167, 1979.

DODMAN, N.H. et. al. Aging changes in the geriatric dog and their impact on anesthesia. Compend Contin Educ Pract Vet, v.6, p.1106-1113, 1984.
ETTINGER, S.J. Electrocardiography. In: ETTINGER, S.J.; FELDMAN, E.C. Textbook of veterinary internal medicine. 5.ed. Philadelphia: Saunders, 2000. p.800-833.

GOLDSTON, R.T. Geriatrics and gerontology. Vet Clin North Am, v.19, p.1-202, 1989.

HUBBEL, J.A.E. et al. Change of inhalation anesthetic agents for management of ventricular premature despolarizations in anesthetized cats and dogs. J Am Vet Med Assoc, v.185, p.643-646, 1984.

MUIR, W.W. Anesthetics and techniques. In: SLATTER, D. Textbook of small animal surgery. 2.ed. Philadelphia: Saunders, 1993. p.2245-2250.

NUNES, N. Monitoração da anestesia. In: FANTONI, D.T.; CORTOPASSI, S.R.G. Anestesia em cães e gatos. São Paulo: Roca, 2002. Cap.6, p.64-81.

OWENS, W. The geriatric patient - physiology of aging. Proc Am Soc Anesthesiol, v.275, p.A1-A4, 1985.

PADDLEFORD, R.R. Manual of small animal anesthesia. Philadelphia: Saunders, 1999. p.267-317.

ROBINSON, E.P. Pediatric and geriatric anesthetic techniques. In: SLATTER, D. Textbook of small animal surgery. 2.ed. Philadelphia: Saunders, 1993. p.2295-2300.

SCHMIDLIN, O. et.al. Effects of physiological aging on cardiac electrophysiology in perfused Fischer 344 rat hearts. Am J Physiol, v.262, p.97, 1992.

SPINOSA, H.S.; GÓRNIAK, S.L. Tranqüilizantes e relaxantes de ação central. In: SPINOSA, H.S. et al. Farmacologia aplicada à medicina veterinária. Rio de Janeiro: Guanabara Koogan, 1999. p.140-149.

STEFFEY, E.P. Inhalation anesthetics. In: THURMON, J.C. et. al. Lumb and Jones veterinary anesthesia. 3.ed. Baltimore: Williams \& Wilkins, 1996. p.297.

STOELTING, R.K. Inhaled anesthetics. In: Pharmacology and physiology in anesthetic practice. 3.ed. Philadelphia: Lippencott-Raven, 1999. p.36-76.

TOLDO, A. et al. Anestesia em geriatria. In: YAMASHITA, A.M. et al. Anestesiologia - SAESP. 5.ed. São Paulo: Atheneu, 2001. p.971-980.

ZAIDAN, J.R. Eletrocardiografia. In: BARASH, P.G. et al. Tratado de anestesiologia clínica. São Paulo: Manole, 1993. p.709-748. 